\title{
Biological activity and functional diversity in soil in different cultivation systems
}

\author{
S. Jezierska-Tys ${ }^{1} \cdot$ S. Wesołowska ${ }^{2} \cdot$ A. Gałązka ${ }^{3} \cdot$ J. Joniec $^{1}$ (D) · J. Bednarz ${ }^{1} \cdot$ R. Cierpiała ${ }^{4}$
}

Received: 5 December 2019 / Revised: 27 April 2020 / Accepted: 4 May 2020 / Published online: 17 May 2020

(c) The Author(s) 2020

\begin{abstract}
The aim of the work was to evaluate the impact of use of conventional and organic cultivation systems on selected parameters of microbial activity in the soil under wheat, barley and oat cultivation. Microbiological, biochemical, enzymatic and metabolic activities were analyzed during three seasons over 3 years in soil. The more beneficial effect of organic cultivation was reflected in the increase in bacterial growth, the intensification of the nitrification and higher activity of all analyzed enzymes. The conventional system was more favorable for the development of fungi. The assessment of the metabolic profile of soil microorganisms demonstrated clear differences between the activity of microorganisms in the organic and conventional systems. The results indicate that cultivation of soil in the organic system is more conducive to the environment. The authors conducted research, because there is no unambiguous answer to the question which growing system is more beneficial for soil biological life, i.e., the basis for food production. Microorganisms that are the object of these studies form the basis for the fertility of all soil ecosystems.
\end{abstract}

Editorial responsibility: Jing Chen.

\section{J. Joniec}

jolanta.joniec@up.lublin.pl

1 Department of Environmental Microbiology, Faculty of Agrobioengineering, University of Life Sciences in Lublin, Leszczyńskiego 7, 20-069 Lublin, Poland

2 Faculty of Agrobioengineering, Institute of Soil Science, Environment Engineering and Management, University of Life Sciences in Lublin, Leszczyńskiego 7, 20-069 Lublin, Poland

3 Department of Agricultural Microbiology, Institute of Soil Science and Plant Cultivation, State Research Institute, Czartoryskich 8, 24-100 Puławy, Poland

4 Department of Herbology and Plant Cultivation Techniques, Faculty of Agrobioengineering, University of Life Sciences in Lublin, Akademicka 13, 20-950 Lublin, Poland 


\section{Graphic abstract}

\section{conventional tillage}

\section{pesticides}

mineral fertilization

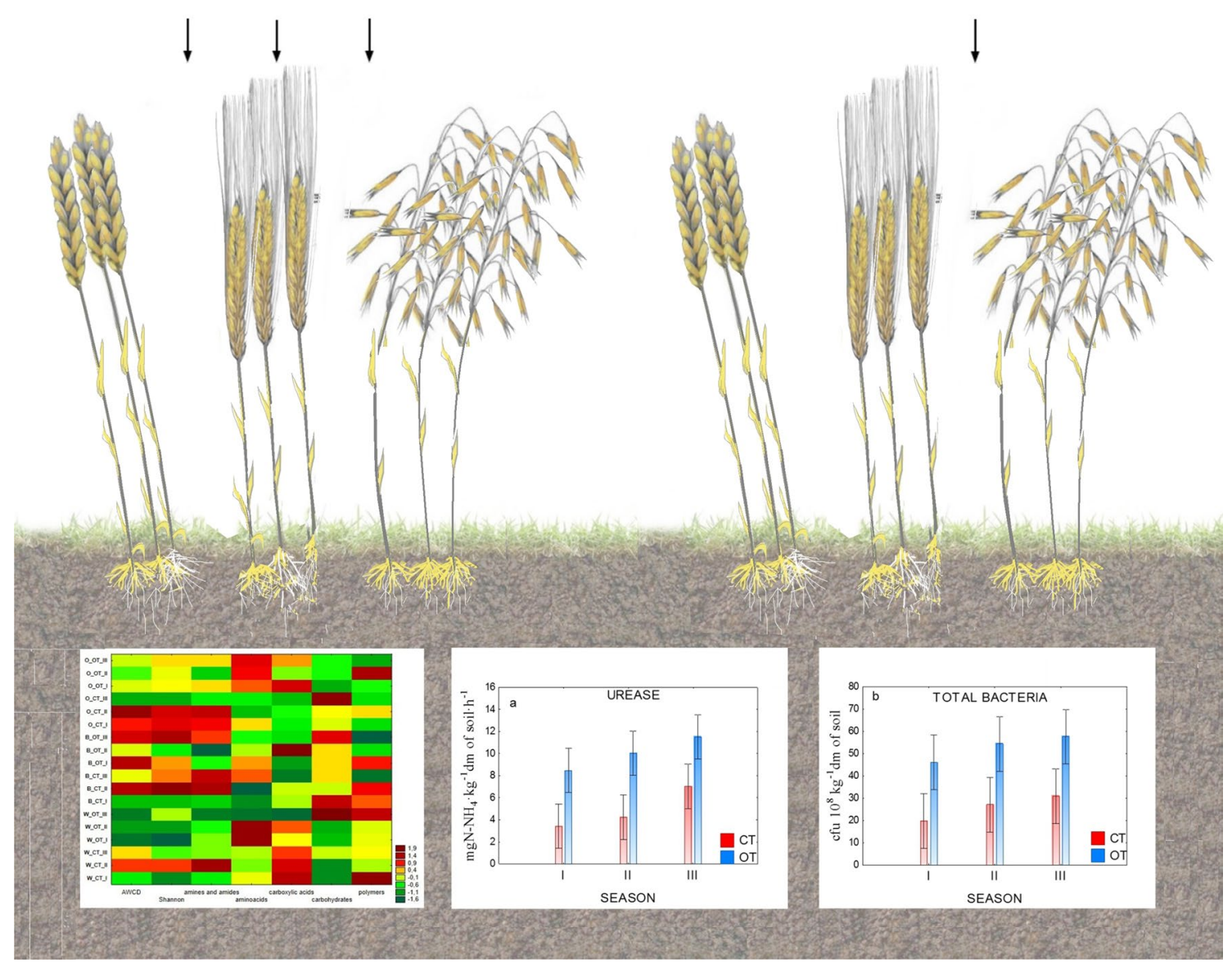

\section{organic tillage}

\section{manure}

Keywords Bacteria and fungi $\cdot$ Enzymatic activity $\cdot$ Metabolic profile

\section{Introduction}

Soils play a key role in defining sustainable land management, as they form the basis of food production (Fließbach et al. 2007). Microorganisms are an integral part of the soil and at the same time the basis of its functioning. Soil microorganisms play a critical role in maintaining soil fertility and quality (Zhang et al. 2010). They are responsible, among others, for nutrient cycle, bioavailability and environmental detoxification. However, various human pressures have a negative impact on soil microbial communities, which consequently leads to disturbance of the functioning of soil ecosystems and decrease in soil productivity (Gouda et al. 2017). The activity and diversity of soil microorganisms are widely regarded as a sensitive indicator of the state of a given environment, because they are a living component of the soil environment that rapidly reacts to anthropogenic factors (Nannipieri et al. 2002). Many authors use the number of microorganisms, their diversity, biochemical and enzymatic activity, among others, to assess the impact of different soil cultivation methods on agro-ecosystems. Studies of Chhotaray and Achakzai (2012), Baćmaga et al. (2016), Gajda et al. (2016), Mommer et al. (2016) and Oszust et al. (2014) indicated the sensitivity of these parameters of microbial activity to various types of fertilization, the use of different plant protection products, cultivation treatments or the effect of root exudates of the cultivated plant. The analysis 
of the metabolic profile of soil microorganisms is a very good indicator in assessing the quality of the soil environment, especially in the context of long-term studies. Such research was conducted by Gałązka et al. (2017a, b).

Populations in the era of enormous technological progress and demographic growth are still struggling with the problem of sustenance in many regions of the world. It is a problem not only of the governments of individual countries, but also of scientists researching the methods of agricultural space management. There are three cultivation systems in modern agriculture: conventional, organic and integrated. Many scientific reports concern the discussion of the advantages and disadvantages of these systems (Bünemann et al. 2006; De Ponti et al. 2012; Liang et al. 2014; Seufert et al. 2012; Stephens et al. 2018). A high yield in the conventional system is obtained using intensive fertilization and chemical plant protection. This leads to the deterioration of biological and physicochemical properties of the soil and thus its degradation. The possibility of resistance occurrence in pathogens is an unfavorable phenomenon related to the long-term use of pesticides (R4P Network 2016). Intensive mineral fertilization leads, among others, to acidification (Bünemann et al. 2006). Conditions are created for the development of fungi, including pathogens, which cause deterioration in the technological value of agricultural products (Frąc et al. 2015). An environmentally friendly system is a system that excludes the use of chemical plant protection products. In addition, organic instead of mineral fertilization is applied. Therefore, plant nutrition in organic farming is based on natural mineralization products of organic matter behind, for which soil microorganisms are responsible. Organic farming leads to an optimal yield of high biological quality and good storage quality. It is a system that does not cause environmental degradation. However, critics say that organic farming can obtain lower yields, and therefore, it needs more land to produce the same amounts of food as in traditional farms. This phenomenon leads to higher deforestation and loss of biodiversity, thereby undermining the environmental benefits of organic practices (Seufert et al. 2012).

The conducted research was aimed at a comprehensive assessment of the impact of the conventional and organic system on the number, diversity and activity of microorganisms in the soil during wheat, barley and oat cultivation.

Research subject is current on a global scale. Research is not only relevant on a local scale, but applies to different climatic zones, soils and crops. Microorganisms that are the object of these studies form the basis for the fertility of all soil ecosystems.

This study was conducted in the years 2014-2016 in the Department of Environmental Microbiology of the University of Life Science in Lublin, Poland, and in the Department of Agricultural Microbiology, Institute of Soil Science and Plant Cultivation, in Puławy, Poland.
Table 1 Chemical characteristics of soil used in the experiment (spring 2014)

\begin{tabular}{llr}
\hline Parameter & Unit & Value \\
\hline $\mathrm{C}_{\text {org }}$ & $\mathrm{g} \mathrm{kg}^{-1} \mathrm{~d} . \mathrm{m}$ & 6.81 \\
Total N & $\mathrm{g} \mathrm{kg}^{-1} \mathrm{~d} . \mathrm{m}$ & 0.81 \\
Total P & $\mathrm{mg} \mathrm{kg}^{-1} \mathrm{~d} . \mathrm{m}$ & 88.00 \\
$\mathrm{~K}$ & $\mathrm{mg} \mathrm{kg}^{-1} \mathrm{~d} . \mathrm{m}$ & 175.00 \\
$\mathrm{Mg}$ & $\mathrm{mg} \mathrm{kg}^{-1} \mathrm{~d} . \mathrm{m}$ & 16.20 \\
\hline
\end{tabular}

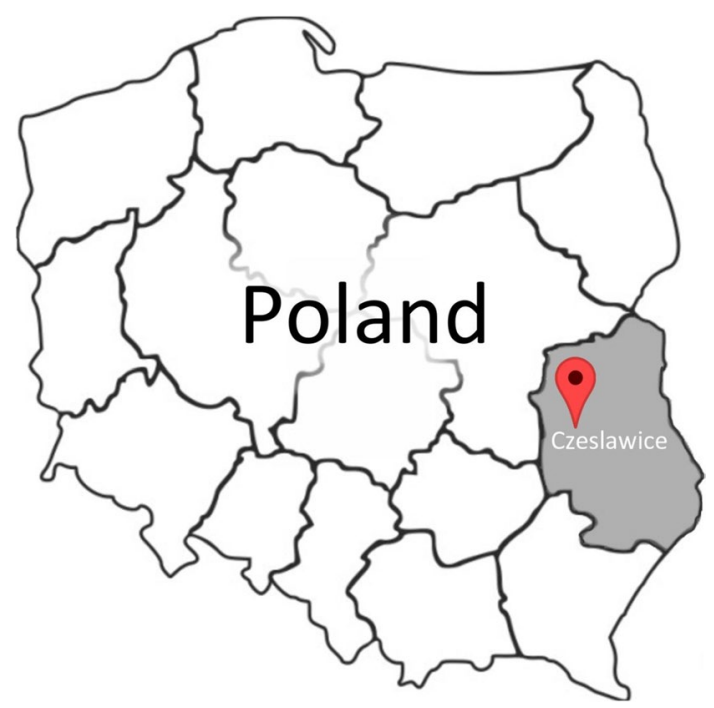

Fig. 1 Location of the study site

\section{Materials and methods}

\section{Experimental model}

The field experiment was established in the autumn of 2008 on the Haplic Luvisol (LV-ha) (IUSS Working Group WRB 2015) formed from loess-like deposits. The chemical characteristics of the soil, assessed before the experiment, are provided in Table 1. The experiment was located in the Experimental Farm of the University of Life Sciences in Lublin, in Czesławice, Poland (51 ${ }^{\circ} 18^{\prime} 23^{\prime \prime}$ N $22^{\circ} 16^{\prime} 02^{\prime \prime}$ E) (Fig. 1). The experimental model was established using the split-block method (plot size of $30 \mathrm{~m}^{2}$ ). The design of the experiment included the cultivation of five plant species in two cultivation systems, i.e., sugar beet (Beta vulgaris L.), spring barley (Hordeum vulgare L.), red clover (Trifolium pratense L.), winter wheat (Triticum aestivum L.) and oat (Avena sativa $\mathrm{L}$.). Soil cultivation for each of these plants was carried out in a typical manner.

The work focuses on the soil from the cultivation of cereal plants, i.e., winter wheat, spring barley and oat. 
Cultivation was carried out in two management systems, i.e., conventional and organic. The organic system did not use chemical plant protection and mineral fertilization. On the other hand, pig manure fertilization at a rate of $30 \mathrm{tha}^{-1}$ was applied every year before plowing. Manures had the following composition: $\mathrm{N}-0.46 ; \mathrm{P}_{2} \mathrm{O}_{5}-0.014 \%$; $\mathrm{K}_{2} \mathrm{O}-0.53 \% ; \mathrm{MgO}-0.15 \%$; and $\mathrm{CaO}-0.56 \%$. The regulation of weed infestation of plant field in the organic system was based solely on mechanical procedures. Mineral fertilization and a set of pesticides listed in Table 2 were used in the conventional cultivation.

\section{Soil samples}

Samples for microbiological and biochemical analyses were collected from the $0-20 \mathrm{~cm}$ layer in spring (first season), summer (second season) and autumn (third season) each time in 2014 (first year), 2015 (second year) and 2016 (third year). The soil samples were collected randomly from the center of each subplot from five sites to sterile containers. Average soil sample from each subplot consisted of a mixture of four soil cores of $4 \mathrm{~cm}$ diameter each. The collected material was sieved through a $2-\mathrm{mm}$ sieve and stored at $4{ }^{\circ} \mathrm{C}$. The experiments were performed at the University of Life Sciences in Lublin, Faculty of Agrobioengineering, Department of Environmental Microbiology, Lublin, Poland, and Department of Agricultural Microbiology, Institute of Soil Science and Plant Cultivation, State Research Institute, Puławy, Poland.

\section{Microbiological analyses}

The plate method was used in soil samples to determine: the total number of bacteria on the medium with soil extract (Trolldenier 1995) and the total number of fungi on Martin's medium (Martin 1950).

\section{Biochemical analyses}

Biochemical analyses included: intensification of the nitrification based on $\mathrm{NO}_{3}{ }^{-}$ion concentration by the Brucine method (Nowosielski 1974).

\section{Enzymatic analyses}

Enzymatic analyses covered measuring the activity of: dehydrogenases with TTC (triphenyl tetrazolium chloride) by Thalmann's method (1968), protease with sodium caseinate as a substrate using the Ladd and Butler method (1972) modified by Alef and Nannipieri (1995), urease activity, which was determined with urea as a substrate by the method of Zantua and Bremner (1975).

\section{Biolog analysis}

The community-level physiological profiling (CLPP) analysis, showing metabolic potential of soil microbial communities, was carried out using Biolog EcoPlates (Biolog Inc., Hayward, CA, USA). The metabolic potential of soil microbial communities was determined using 31 different carbon sources located in five groups (amines and amides, amino acids, carbohydrate, carboxylic acid and polymers) (Pohland and Owen 2009). The methodology included: $1 \mathrm{~g}$ of soil was weighed, transferred to conical flasks holding $99 \mathrm{~cm}^{3}$ of sterile $0.9 \% \mathrm{NaCl}$ each and vortexed for $30 \mathrm{~min}$ at $150 \mathrm{rpm}$ and at $25^{\circ} \mathrm{C}$. In the next step, the samples were cooled for $30 \mathrm{~min}$ to $4{ }^{\circ} \mathrm{C}$, and in the second step, $120 \mathrm{~mm}^{3}$ was transferred to each well in the EcoPlate and incubated in the dark at $25{ }^{\circ} \mathrm{C}$ for $120 \mathrm{~h}$. The experiment was carried out in three replicates on each soil sample. The results were read every $24 \mathrm{~h}$ on the MicroStation ID system. The reduction of colorless tetrazolium chloride to red formazan $(\lambda=590 \mathrm{~nm})$ was used as the method to determine to what extent carbon sources were used by soil microbial communities (Islam et al. 2011). The most intensive metabolism of carbon substrates was observed after $96-120 \mathrm{~h}$ of incubation. The results were expressed as average well color development (AWCD) and Shannon-Weaver (H') indices.
Table 2 Mineral fertilization and pesticides used in the conventional system

\begin{tabular}{llll}
\hline & Winter wheat & Spring barley & Oat \\
\hline NPK mineral fertilization, $\mathrm{kg} \mathrm{ha}^{-1}$ & $160+60+80$ & $90+70+90$ & $70+70+110$ \\
Seed dressing (thiram + tebuconazole) & + & + & + \\
Fungicide (propiconazole + fenpropidin) & + & + & + \\
Fungicide (flusilazole + carbendazim) & + & + & + \\
Insecticide (alpha-cypermethrin + lambda- & + & + & + \\
$\quad$ cyhalothrin) & + & + & + \\
Herbicide (MCPA) & + & - & + \\
Retardant (chlormequat chloride) & + & & + \\
\hline
\end{tabular}




\section{Statistical analysis}

All microbiological, biochemical, enzymatic and chemical analyses were performed in triplicate. Statistical analyses were performed using STATISTICA.PL (10) (Stat. Soft. Inc. USA). The following statistical tests were applied: one-way analysis of variance (ANOVA), PCA (principal component analysis) and Tukey's post hoc HSD test at a significance level of $P<0.05$. The AWCD index was calculated using the formula: AWCD $=\Sigma(C-R) / 95$; where $C=$ absorbance in each well and $R=$ absorbance in the control well (Garland and Mills 1991). The Shannon-Weaver (H') index was calculated according to Gomez et al. (2004).

\section{Results and discussion}

\section{Results}

\section{The number of microorganisms}

The organic wheat cultivation created more favorable conditions for the development of this group of microorganisms in the second year of research $(54.4 \mathrm{cfu})$ and in the second season (55.0 cfu) (Fig. 2a). There was a significant positive impact of the organic system on the number of bacteria in the analyzed seasons (I-46.0 cfu; II-54.3 cfu; III-57.6) and in the second (59.0 cfu) and third (62.3 cfu) year of research under barley cultivation (Fig. 2b). The higher number of bacteria $(46.2 \mathrm{cfu})$ in the soil in oat cultivation
(Fig. 2c) in the organic system in summer is also worth noting. The number of the studied group of microorganisms was at a comparable level in both cultivation systems in the remaining seasons and years.

Our results concerning the number of fungi in the soil under wheat cultivation are illustrated in Fig. 2a. A higher number of fungi were found in soil under wheat cultivation in the conventional system in autumn $(111.1 \mathrm{cfu})$ and in the second year of analyses (90.4 cfu) in comparison with the organic system. The number of fungi in both cultivation systems was at a similar level in other seasons and years of research (Fig. 2b). Both cultivation systems in barley cultivation did not cause significant changes in the number of fungi. Soil conditions in oat cultivation were more conducive to fungal development in the conventional system (Fig. 2c). The number of these microorganisms was significantly higher in the conventional system compared with their number in the organic system in seasons I ( $83.4 \mathrm{cfu})$ and III $(113.1 \mathrm{cfu})$. This effect was also visible in individual years, but the differences were not statistically significant.

\section{Biochemical activity}

The course of the nitrification in the analyzed seasons and years of research is depicted in Fig. 3a, b, c. Higher activity of the nitrification was found in the soil under wheat cultivation in the organic system in spring $\left(137.0 \mathrm{mg} \mathrm{N}-\mathrm{NO}_{3}\right)$ and in the second year (126.0 mg N-NO ${ }_{3}$ ) of the study (Fig. 3a). Nitrification in the soil under barley cultivation proceeded at a similar level in both cultivation systems (Fig. 3b). The high
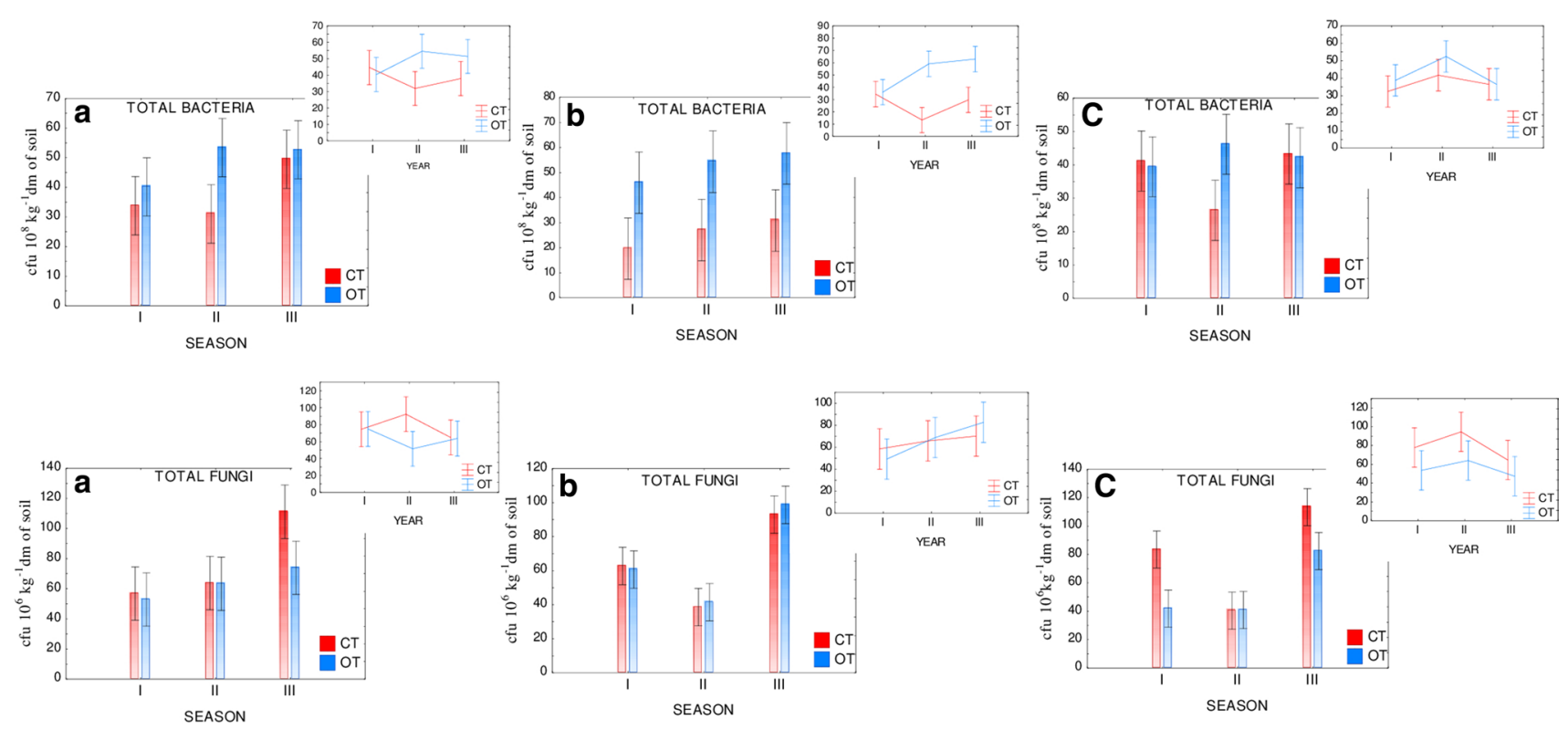

Fig. 2 Number of selected groups of microorganisms in the soil. a Wheat, b barley, c oat, $C T$ conventional tillage, $O T$ organic tillage, season: I-spring, II—summer, III-autumn 

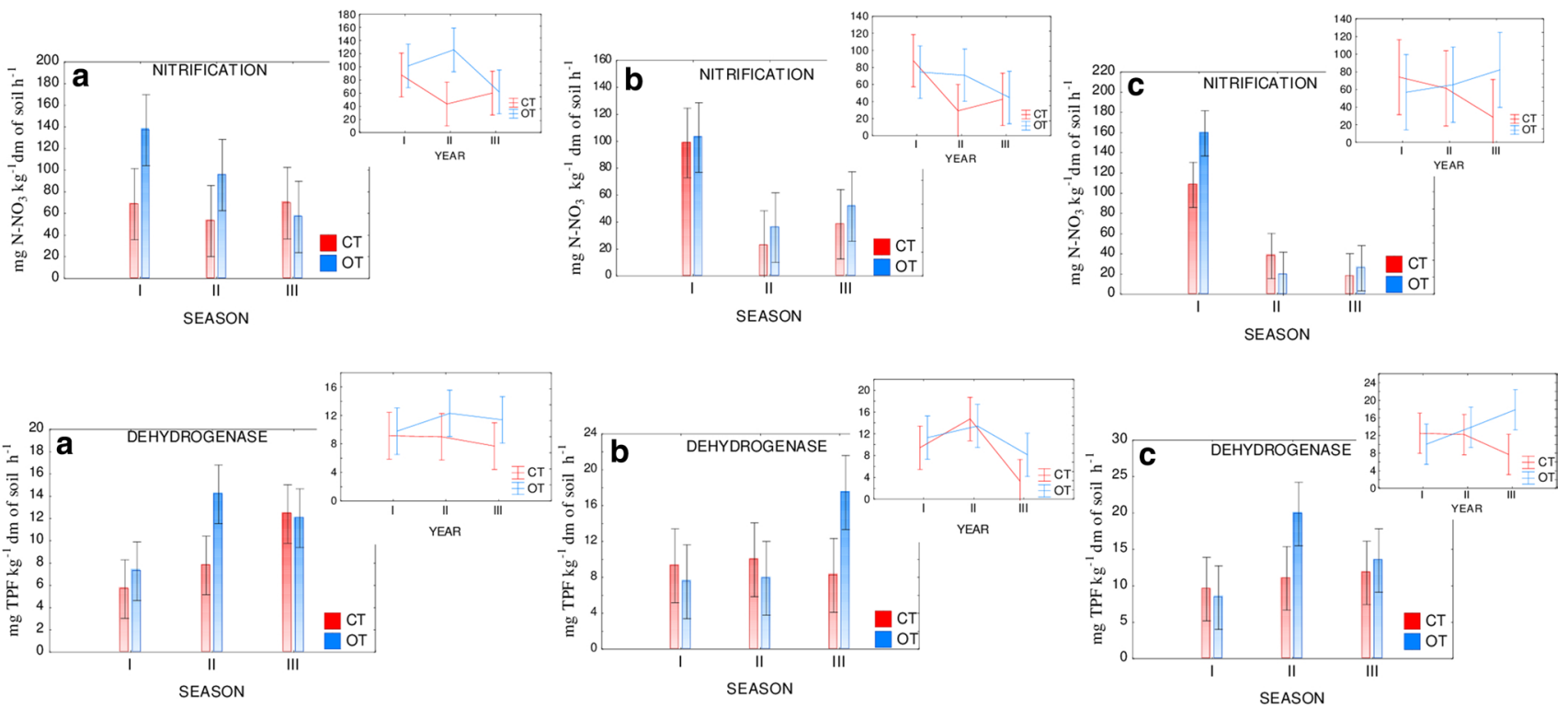

Fig. 3 Biochemical and enzymatic activity in the soil. Explanations as in Fig. 2

intensity of nitrification in the spring (159.3 $\mathrm{mg} \mathrm{N}-\mathrm{NO}_{3}$ ) should be noted in the soil under oat cultivation, similarly as in the case of wheat and barley, also in the organic system (Fig. 3c).

\section{Enzymatic activity}

The results of research on the impact of conventional and organic cultivation systems on dehydrogenase, protease and urease activity in the soil under wheat, barley and oat are shown in Figs. 3 and 4. The organic system had a positive effect on the activity of the enzymes tested in both individual years and seasons. Significantly higher dehydrogenase activities in soil under wheat and oat cultivation were recorded in the organic system compared to the conventional system (Fig. 3a, c). This effect was noted in the second research season (wheat-14.6 mg TPF; oat-19.8 mg TPF) and additionally in the third year (oat $-17.8 \mathrm{mg}$ TPF). The cultivation of barley in the organic system resulted in the
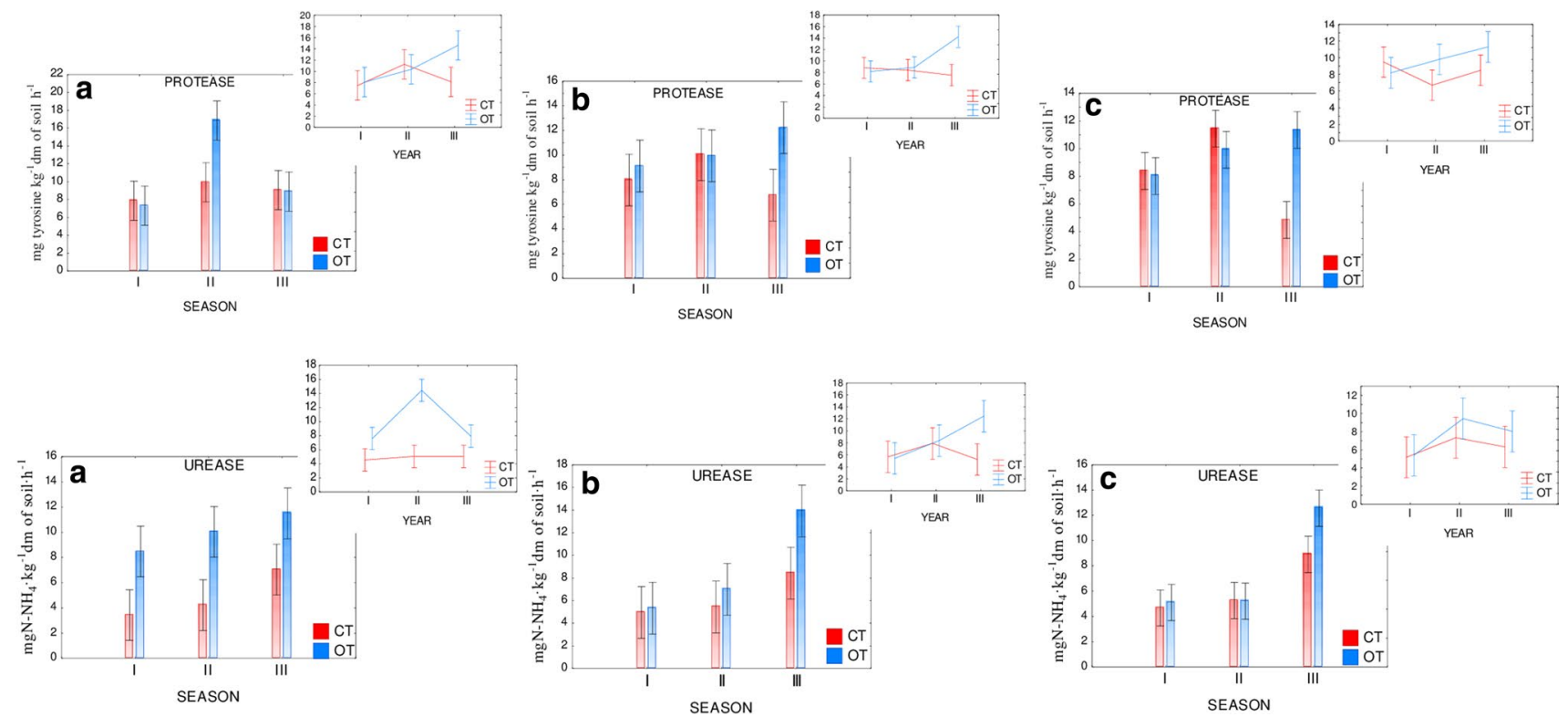

Fig. 4 Enzymatic activity in the soil. Explanations as in Fig. 2 
higher dehydrogenase activity in the soil in the third season (17.5 mg TPF) (Fig. 3b).

Analyzing the activity of protease in the soil under wheat cultivation, higher values of this parameter were found in the soil under organic farming in the summer (16.8 $\mathrm{mg}$ tyrosine) and in the third year (14.6 mg tyrosine) of research (Fig. 4a). The activity of protease in the remaining seasons and years of research was generally at a similar level in both cultivation systems. A significant impact of the ecological system was found in the autumn (barley-12.2 mg tyrosine; oat$11.3 \mathrm{mg}$ tyrosine) and in the third year (barley-14.2 mg tyrosine) of research in the soil under barley and oat cultivation (Fig. 4b, c).

The results indicated a more beneficial effect of cultivation in the organic system on urease activity in the soil under wheat cultivation in all analyzed seasons ( $\mathrm{I}-8.5 \mathrm{mg} \mathrm{N}^{-\mathrm{NH}_{4}}$; II-10.0 $\mathrm{mg} \mathrm{N}-\mathrm{NH}_{4}$; III- $11.7 \mathrm{mg} \mathrm{N}-\mathrm{NH}_{4}$ ) as well as in years $\left(\mathrm{I}-7.6 \mathrm{mg} \mathrm{N}-\mathrm{NH}_{4}\right.$; II-14.4 $\mathrm{mg} \mathrm{N}-\mathrm{NH}_{4}$; III$7.9 \mathrm{mg} \mathrm{N}-\mathrm{NH}_{4}$ ) (Fig. 4a). The positive impact of the organic system was also found in the soil under barley and oat in season III (barley-13.9 mg N-NH

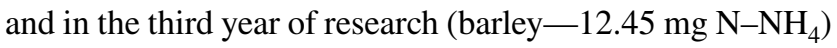
(Fig. 4b, c).

\section{Community-level physiological profiling (CLPP) analysis using Biolog EcoPlates}

The effect of seasons, management practices and plants on microbial community catabolic diversity as evaluated by the Shannon diversity index $(H)$, substrate richness (R), substrate evenness (E) and average well color development $\left(\mathrm{AWCD}_{590}\right)$ in the Biolog EcoPlate incubated for $120 \mathrm{~h}$ is presented in Table 3.

There were statistically significant differences found in the AWCD index in soil for particular plants, cultivation system and the sampling season (Table 3 ). The soil from winter wheat cultivation $(\mathrm{AWCD}=1.631)$ farmed in the conventional system in the third season of sampling was characterized by the highest AWCD value. However, the lowest AWCD value was recorded in the soil from winter wheat cultivation grown in the organic system also in the third season of soil sample collections $(\mathrm{AWCD}=1.314)$. Statistically significant differences in the value of the Shannon index were found between winter wheat and barley grown in the conventional and organic system. The highest value of the Shannon index was found in the soil collected from barley cultivation in the third season of sampling $(H=3.260)$ and the lowest in the soil from winter wheat cultivated in the conventional system also in the third sampling period $(H=3.101)$. Lower microbial richness $(R)$ indices were also found in soils in the organic system.

The effect of different plants on microbial community catabolic diversity as evaluated by substrate utilization in the Biolog EcoPlate incubated for $0-168 \mathrm{~h}$ was measured. The distribution of individual groups of compounds was proportional to the duration of incubation. The highest absorbance readings were observed after $120 \mathrm{~h}$. Carbohydrates and carboxylic acids were the compound group most easily utilized
Table 3 Effect of seasons, management practices and plants on microbial community catabolic diversity as evaluated by the Shannon's diversity index $(H)$, substrate richness $(R)$, substrate evenness $(E)$ and average well color development $\left(\mathrm{AWCD}_{590}\right)$ in the Biolog EcoPlate incubated for $120 \mathrm{~h}$

\begin{tabular}{lllll}
\hline Sample & $H$ & $R$ & $E$ & AWCD 590 \\
\hline wheat_CT_I & $3.201^{\mathrm{a}} \pm 0.037$ & $26.000^{\mathrm{b}} \pm 1.000$ & $0.983^{\mathrm{a}} \pm 0.011$ & $1.442^{\mathrm{b}} \pm 0.069$ \\
wheat_CT_II & $3.136^{\mathrm{b}} \pm 0.036$ & $24.000^{\mathrm{b}} \pm 1.000$ & $0.987^{\mathrm{a}} \pm 0.003$ & $1.355^{\mathrm{b}} \pm 0.094$ \\
wheat_CT_III & $3.247^{\mathrm{a}} \pm 0.007$ & $28.667^{\mathrm{a}} \pm 1.528$ & $0.968^{\mathrm{c}} \pm 0.007$ & $1.631^{\mathrm{a}} \pm 0.120$ \\
wheat_OT_I & $3.129^{\mathrm{b}} \pm 0.069$ & $23.333^{\mathrm{c}} \pm 0.517$ & $0.995^{\mathrm{a}} \pm 0.014$ & $1.338 \pm 0.109$ \\
wheat_OT_II & $3.239^{\mathrm{a}} \pm 0.020$ & $26.667^{\mathrm{b}} \pm 0.577$ & $0.987^{\mathrm{b}} \pm 0.012$ & $1.547^{\mathrm{a}} \pm 0.112$ \\
wheat_OT_III & $3.101^{\mathrm{b}} \pm 0.030$ & $24.667^{\mathrm{c}} \pm 0.577$ & $0.968^{\mathrm{c}} \pm 0.007$ & $1.314^{\mathrm{b}} \pm 0.040$ \\
barley_CT_I & $3.191^{\mathrm{b}} \pm 0.044$ & $26.333^{\mathrm{b}} \pm 2.082$ & $0.976 \pm 0.012$ & $1.418^{\mathrm{b}} \pm 0.111$ \\
barley_CT_II & $3.209^{\mathrm{a}} \pm 0.024$ & $26.333^{\mathrm{b}} \pm 0.577$ & $0.981^{\mathrm{b}} \pm 0.009$ & $1.604^{\mathrm{a}} \pm 0.115$ \\
barley_CT_III & $3.260^{\mathrm{a}} \pm 0.025$ & $27.667^{\mathrm{b}} \pm 1.155$ & $0.982^{\mathrm{b}} \pm 0.006$ & $1.580^{\mathrm{a}} \pm 0.050$ \\
barley_OT_I & $3.194^{\mathrm{b}} \pm 0.036$ & $27.000^{\mathrm{b}} \pm 1.000$ & $0.969^{\mathrm{c}} \pm 0.002$ & $1.452^{\mathrm{b}} \pm 0.036$ \\
barley_OT_II & $3.165^{\mathrm{b}} \pm 0.063$ & $26.333^{\mathrm{b}} \pm 2.309$ & $0.969^{\mathrm{c}} \pm 0.008$ & $1.488^{\mathrm{b}} \pm 0.100$ \\
barley_OT_III & $3.137^{\mathrm{b}} \pm 0.049$ & $24.667^{\mathrm{bc}} \pm 1.155$ & $0.979^{\mathrm{b}} \pm 0.004$ & $1.364^{\mathrm{b}} \pm 0.114$ \\
oat_CT_I & $3.224^{\mathrm{a}} \pm 0.031$ & $27.333^{\mathrm{b}} \pm 1.528$ & $0.975^{\mathrm{b}} \pm 0.008$ & $1.535^{\mathrm{a}} \pm 0.034$ \\
oat_CT_II & $3.174^{\mathrm{b}} \pm 0.021$ & $27.333^{\mathrm{b}} \pm 1.528$ & $0.960^{\mathrm{c}} \pm 0.010$ & $1.322^{\mathrm{b}} \pm 0.030$ \\
oat_CT_III & $3.152^{\mathrm{b}} \pm 0.046$ & $24.333^{\mathrm{b}} \pm 1.155$ & $0.988^{\mathrm{a}} \pm 0.002$ & $1.451^{\mathrm{b}} \pm 0.113$ \\
oat_OT_I & $3.218^{\mathrm{a}} \pm 0.028$ & $27.333 \mathrm{~b} \pm 0.577$ & $0.973^{\mathrm{b}} \pm 0.012$ & $1.466 \mathrm{a} \pm 0.023$ \\
oat_OT_II & $3.278^{\mathrm{a}} \pm 0.015$ & $29.000^{\mathrm{a}} \pm 0.00$ & $0.974^{\mathrm{b}} \pm 0.004$ & $1.602^{\mathrm{a}} \pm 0.070$ \\
oat_OT_III & $3.125^{\mathrm{b}} \pm 0.019$ & $24.667^{\mathrm{b}} \pm 1.528$ & $0.976^{\mathrm{b}} \pm 0.015$ & $1.393^{\mathrm{b}} \pm 0.027$ \\
\hline
\end{tabular}

The values are means \pm standard error $(n=3)$. Treatment means separated by different letters are significantly differ (Tukey's mean separation test, $P<0.05$ ) 
by microorganisms. The lowest absorbance values were observed when amines, amides and polymers were utilized (Fig. 5). There were statistically significant differences in the use of particular groups of compounds by microorganisms in soils depending on the cultivation system, sampling season and the type of plant cultivated.

It was found during the $120 \mathrm{~h}$ incubation of the Biolog EcoPlates that the highest metabolic activity of the microorganisms, when utilizing carboxylic acids, was observed in the soil from winter wheat cultivation in the conventional system in all sampling seasons (Fig. 5). In turn, the highest metabolic activity of microorganisms, with respect to the use of amino acids, was observed in the soil from winter wheat and oat cultivation in the organic system. The greatest variation in microbial activity was observed during carbohydrate and polymer utilization as a carbon source regardless of the cultivation system, season and plant.

Strong positive correlations have been demonstrated, based on the PCA, between individual parameters of soil biological activity and indices of this activity obtained by the Biolog method. Strong positive correlations were found between the Shannon index and the AWCD index and the utilization of amino acids as well as amines and amides by microorganisms as carbon sources. The PCA showed higher biological activity expressed by the AWCD and Shannon index in organic oat cultivation in the first and second sampling seasons (Fig. 6a). The highest activity of microorganisms in the utilization of polymers, carboxylic acids and amino acids in the analysis of soil samples, on the example
Fig. 6 Principal component analysis (PCA) of biodiversity indexes and Biolog EcoPlates date incubated for $120 \mathrm{~h}$ from soil samples. a bi-plot analysis, $\mathbf{b}$ wheat, $\mathbf{c}$ barley, $\mathbf{d}$ oat. $C T$ conventional tillage, $O T$ organic tillage; I, II, III years; $W$ wheat, $B$ barley, $O$ oat

of winter wheat cultivated in the organic and conventional system, was demonstrated in the first and third seasons of soil sampling in the organic system. The highest activity of amine and amide utilization and a strong positive correlation with the value of the Shannon and the AWCD index were found in the soil under the cultivation of winter wheat in the organic system in the second season of research (Fig. 6b). As regards barley cultivation, a strong positive correlation with the value of the Shannon and AWCD indices, the utilization of carbohydrates and amines and amides was found in the conventional system (Fig. 6c). The highest variation in the activity of carbon source utilization and biological activity depending on the cultivation system was found in the case of oat cultivation (Fig. 6d). A dendrogram showing the distribution of the analyzed soil samples with respect to each other is shown on the basis of sample analysis by Ward's method using the square of the Euclidean distance (Fig. 7). The dendrogram was prepared with scaled bond distances on the axis (Ward's method) and boundary marked according to Sneath's criteria (33\% and $66 \%$, respectively). The analysis included data obtained from the Biology EcoPlate analysis during both the 120-h incubation of the plates and the basic soil biological activities analyzed in this study. Three main groups and five subgroups were distinguished based on this
Fig. 5 Heat maps for the carbon utilization patterns of the substrates located only on the Biolog EcoPlates date incubated for $120 \mathrm{~h}$ from soil samples. $C T$ conventional tillage, $O T$ organic tillage; I, II, III years

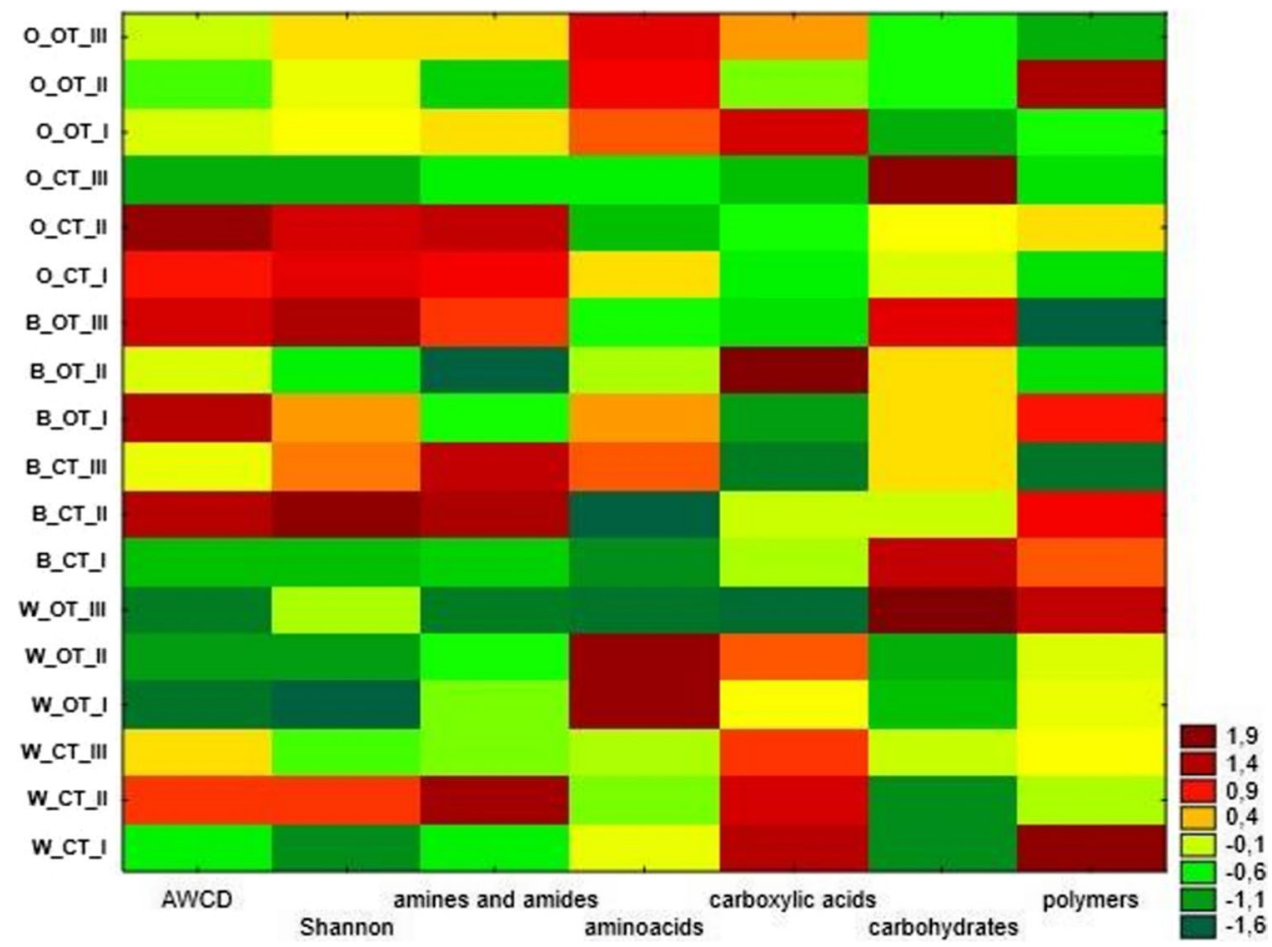



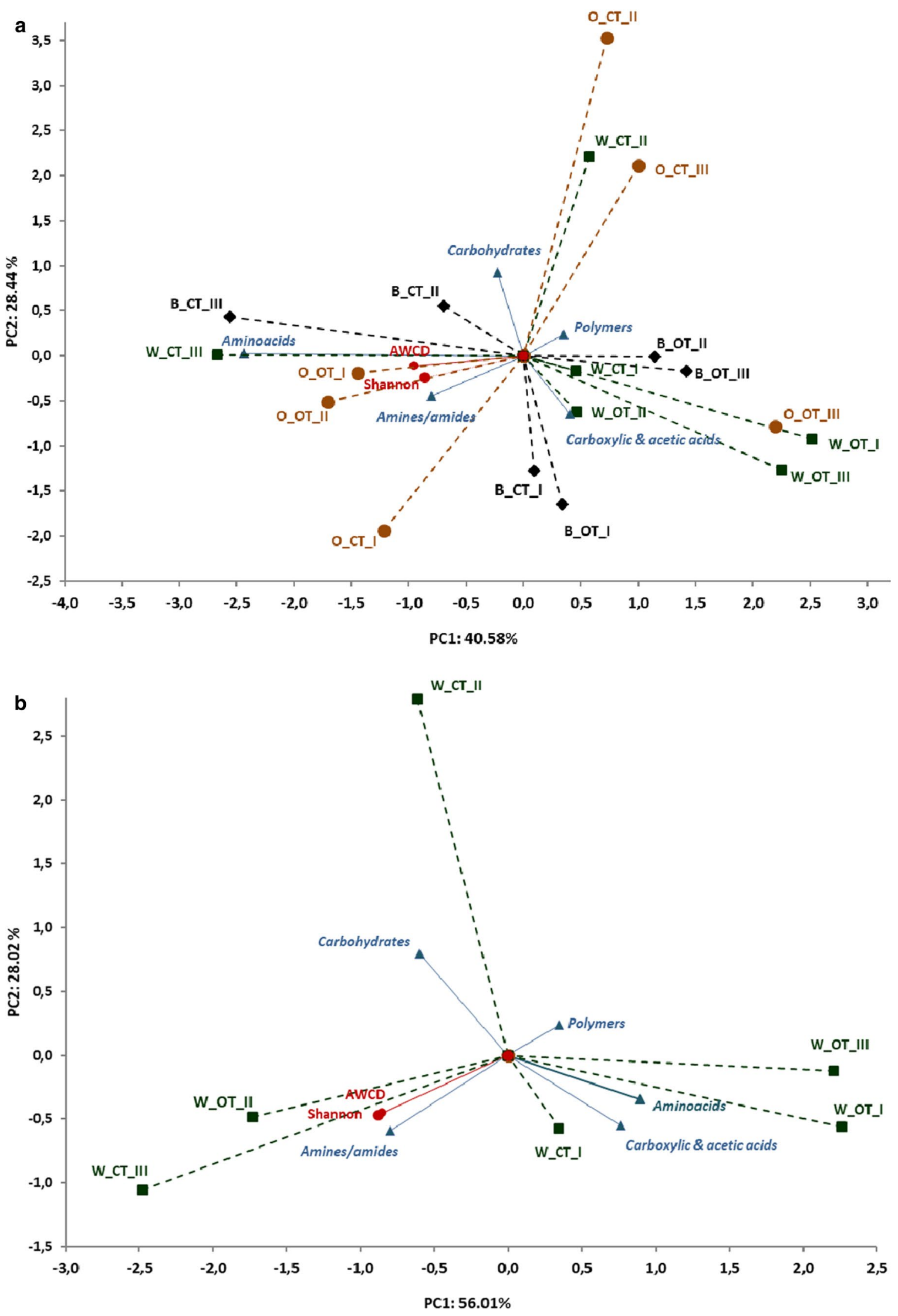

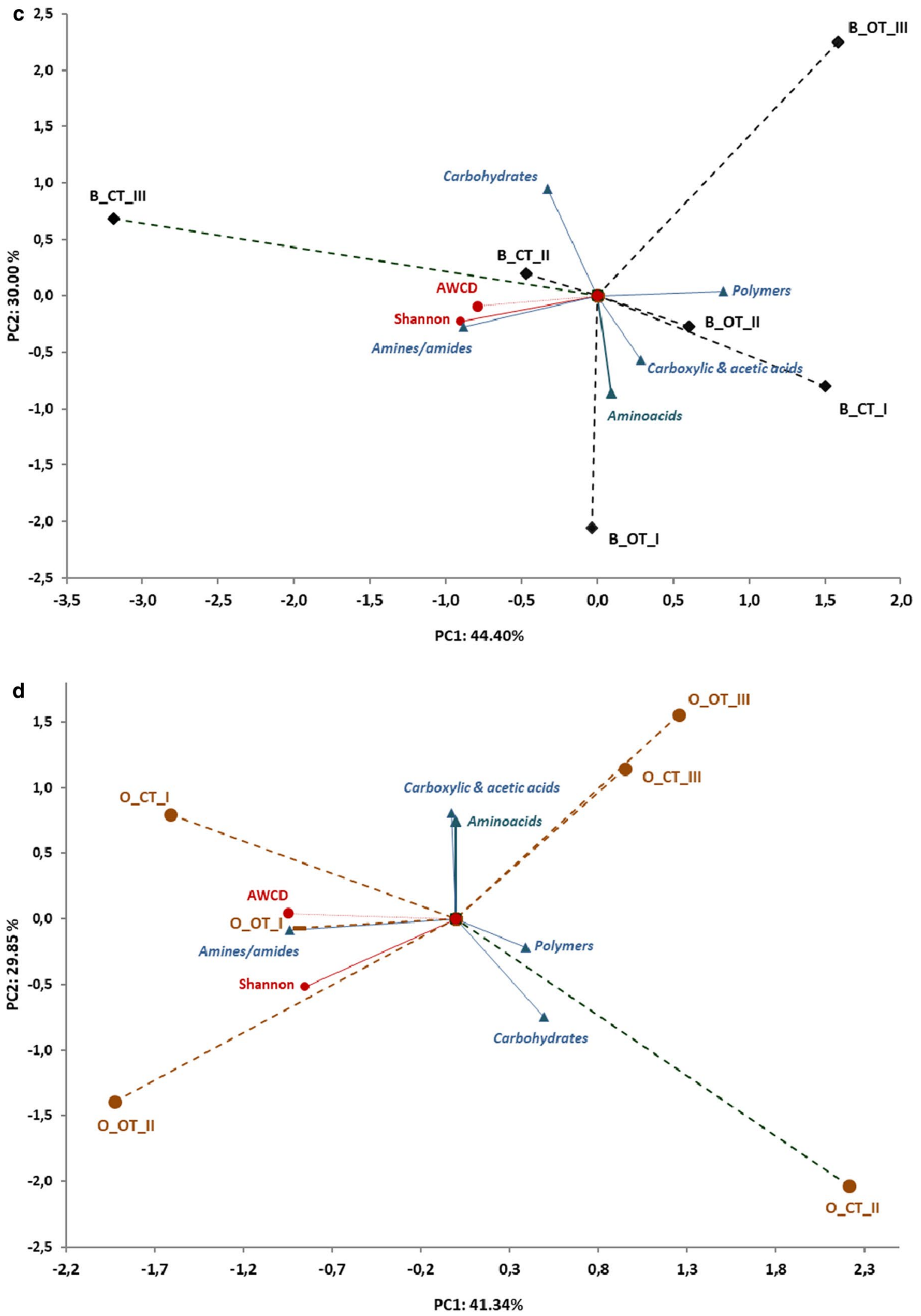

Fig. 6 (continued) 
Fig. 7 Dendrogram of the bond distances between the carbon utilization patterns of the substrates located on the Biolog EcoPlates $(120 \mathrm{~h})$ and microbiological indicators Explanations as in Fig. 5

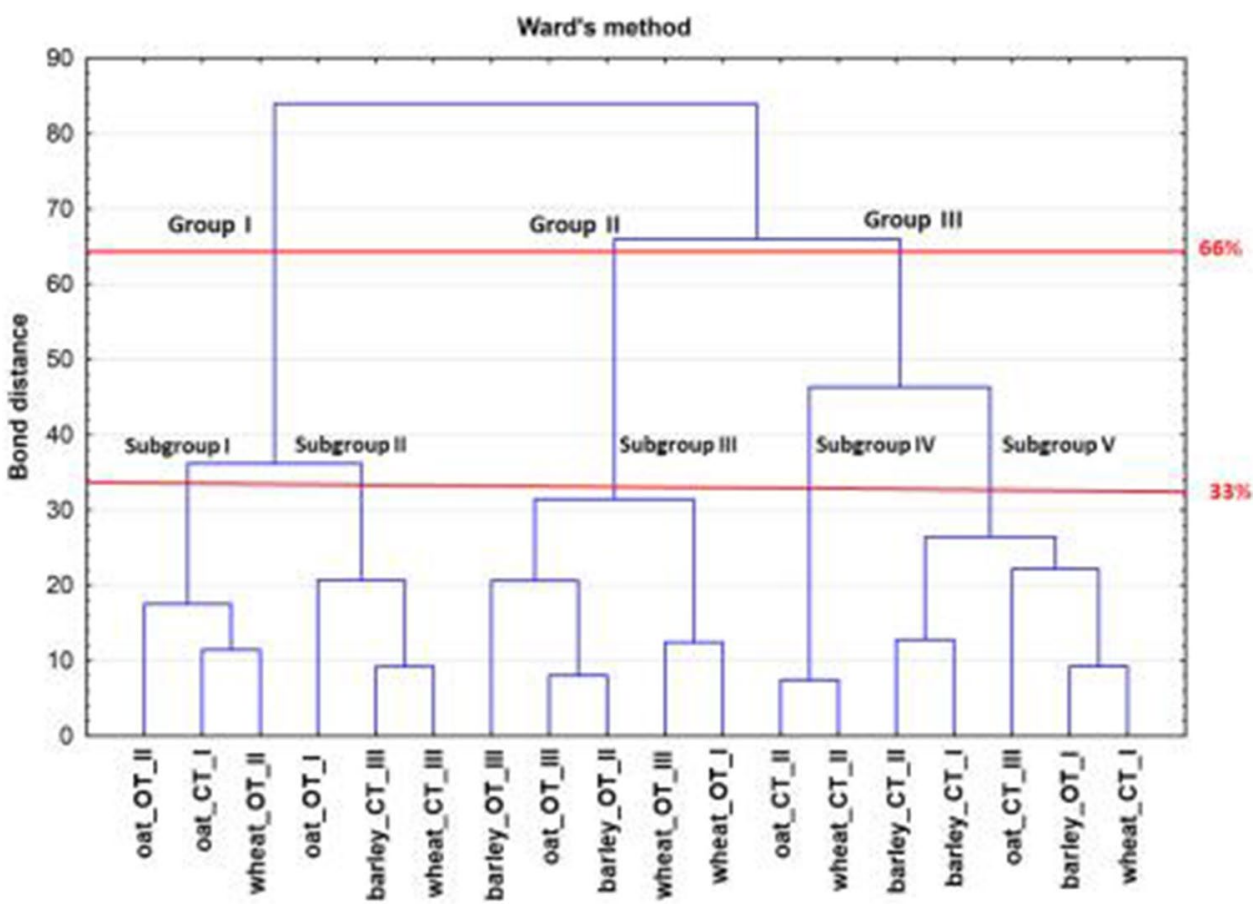

method. It was found that the biological activity in soil varies greatly depending on the cultivation system. Based on the analysis of the main components, there were strong positive correlations between the total number of bacteria, the activity of dehydrogenases, fungi, urease and the utilization of carboxylic acids, amino acids and polymers as a carbon source in the organic system of wheat, barley and oat cultivation in the third year of analysis. On the other hand, strong positive correlations were found between the utilization of carbohydrates and nitrification in the conventional system (Fig. 8a, b).

\section{Discussion}

\section{The number of microorganisms}

The number of microorganisms and their biodiversity is considered to be a good parameter for indicating soil quality (Caldwell 2005). The three-year study conducted on a longterm field experiment indicated differences in the impact of not only the cultivation system, but also the cultivated plant. The soil from cultivation of all three plants farmed in the organic system was characterized by the higher number of bacteria in comparison with the conventional one. However, it should be noted that the apparently positive impact of the organic system became more visible in the soil under barley cultivation. This effect was visible in all seasons as well as in the majority of years in the form of a significantly higher number of bacteria. These observations indicated the impact of not only the system of plant cultivation, but also the root exudates of the cultivated plant. The literature on the subject shows that root exudates play an important role in the development and activity of soil microorganisms (Haichar et al. 2014; Mommer et al. 2016). Similar results were obtained by other authors (Breza-Boruta 2013; BrezaBoruta and Paluszak 2006). They found a more beneficial effect of plant vegetation period and potato rhizosphere on the number of amylolytic and cellulolytic microorganisms in organic systems compared with conventional ones. Chhotaray and Achakzai (2012) studied the effect of a conventional and organic system on soil bacteria and observed greater biomass of these microorganisms in soils cultivated in the organic system. They also found the dependence of this parameter on the season. The observed more beneficial effect of the ecological system on bacterial growth in the soil was probably related to the increase of organic matter in it. Gajda et al. (2016) found an increase in this parameter in the soil cultivated in the organic system. The dependence of the development of soil microorganisms on the organic matter concentration in the environment is commonly known. The less favorable effect of the conventional system on bacterial growth in the soil was probably related to the intensive use of pesticides in this system. The bacterial sensitivity to these plant protection agents was reported, among others, by Baćmaga et al. (2016).

Fungi in the soil play the role of saprophytes, reducers, symbionts and have a huge function in obtaining crop yields. They participate in the processes of complex organic compound decomposition, they enter into symbiosis with 

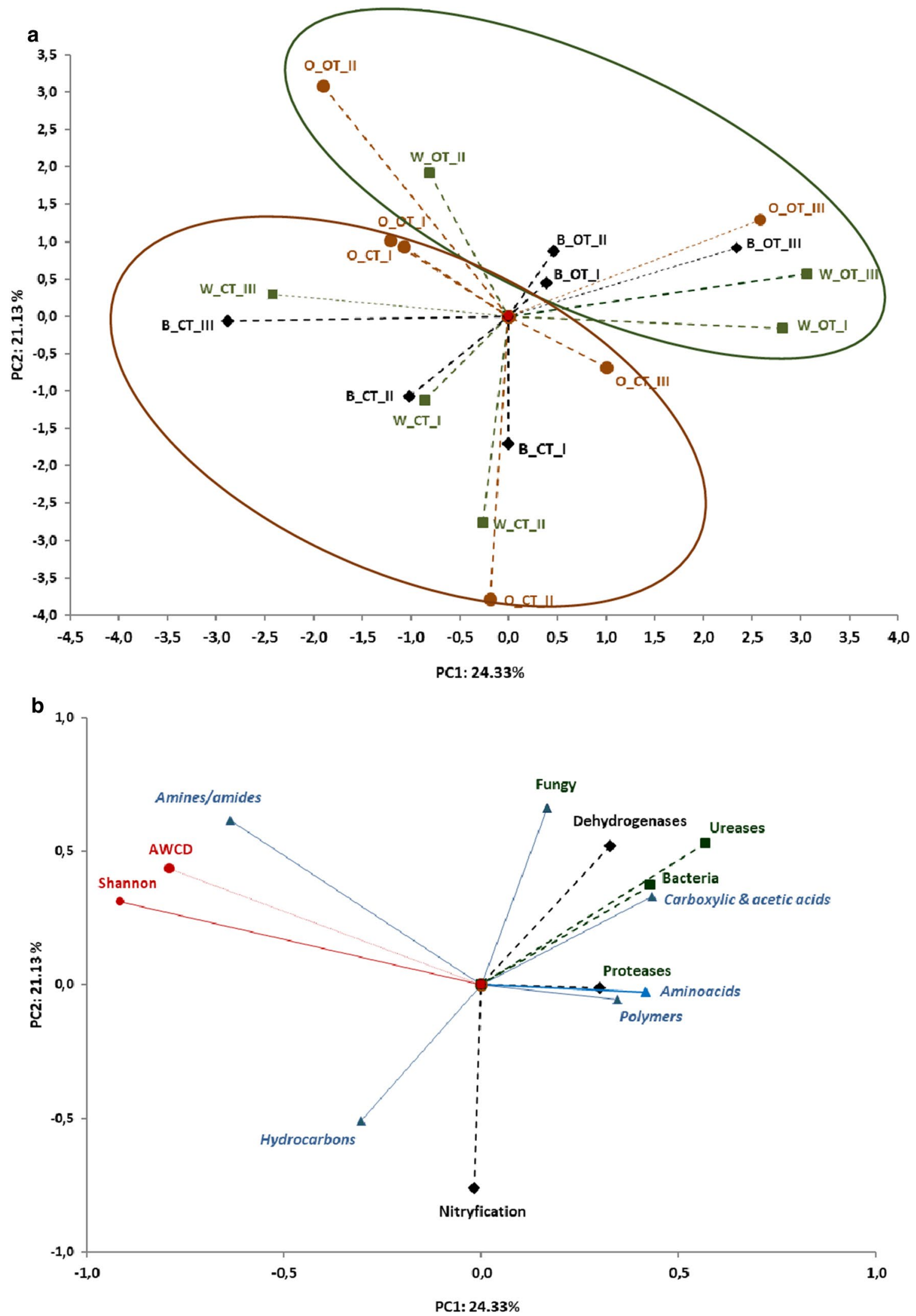

Fig. 8 Principal component analysis (PCA) of microbial parameters, biodiversity indexes and Biolog EcoPlates date incubated for $120 \mathrm{~h}$ from soil samples: a cases, b variables. $C T$ conventional tillage, $O T$ organic tillage; I, II, III years; $W$ wheat, $B$ barley, $O$ oat 
plants, they produce pigments, antibiotics, biologically active compounds, and they shape the soil structure (Anilkumar et al. 2017). Our research showed that the development of these groups of microorganisms was influenced by the cultivation system and the cultivated plant. There was a stimulating effect of the conventional system on the number of fungi in the soil under wheat and oat cultivation. The lack of this effect in the soil in barley cultivation suggested that root exudates played a significant role. The literature on the subject shows that the use of pesticides does not always have an unambiguous effect on soil microorganisms. The authors of these studies indicate both inhibitory and stimulating effects of these preparations on the development of fungi and actinomyces (Crouzet et al. 2010; Sebiomo et al. 2011). Upadhyay and Dutt (2017) reported that there are species among fungi and actinomyces that use pesticides as a source of carbon, nitrogen, phosphorus or sulfur. Mineralizing these xenobiotics, they contribute to their detoxification. An additional food source in the form of pesticides applied in conventional cultivation probably contributed to the stimulation of the development of fungi in the context of the present experiment. In addition, this effect may have been caused by lower competition of these microorganisms with bacteria, which showed a more intensive development in the soil of the organic system. It should be noted that a more intensive development of these microorganisms in the soil from the conventional system could be an unfavorable phenomenon. Under such conditions, there is a risk of multiplication of toxinogenic or pathogenic species (Frąc et al. 2015). In addition, excessive production of antibiotics by this microorganism may result in a decline in soil biodiversity from conventional cultivation.

\section{Biochemical activity}

Soil microorganisms are, among others, responsible for processes related to the circulation of the most important biogenic element for plant nutrition, i.e., nitrogen. Nitrification is one of the key microbiological processes affecting crop yield. The decrease in the nitrification in the soil from organic cultivation probably resulted from the negative impact of pesticides on this process. Kinney et al. (2005) and Lang and Cai (2009) showed toxic effects of pesticides on nitrifying bacteria. The nitrification in the soil cultivated in the organic system was more intense than in the soil under the conventional system. These observations indicate that nitrogen transformations under such conditions occur without disturbances.

\section{Enzymatic activity}

The activity of all enzymes analyzed in this study, i.e., dehydrogenases, proteases and ureases, generally showed a higher level in organic soil. However, Madejón et al. (2009) also showed a beneficial effect of conventional cultivation on enzymatic activity in the soil in the cultivation of different barley cultivars. These observations suggest that root exudates play a role in shaping these enzymatic parameters. Other authors like Oszust et al. (2014) did not record any significant differences in enzymatic activities in soil cultivated in a conventional and organic system. Pajares et al. (2012) demonstrated a positive effect of the organic cultivation system on the activity, among others, of dehydrogenases, proteases and ureases. According to Mohammadi (2011), organic fertilization was more beneficial for enzymatic activities than mineral fertilization. Liang et al. (2014) also recorded a more positive effect of the organic farming system compared with the conventional one on the activity, among others, of dehydrogenases and urease. The authors indicated organic fertilization as a better way to permanently increase soil fertility. Organic matter introduced with manure probably contributed to the stimulation of the studied enzymatic activities in the soil cultivated in the organic system. The literature review shows that the activity of enzymes depends on the availability of carbon and nitrogen organic matter (Burns et al. 2013; Castillo et al. 2012; Joniec 2018; Pajares et al. 2012). Lower enzymatic activity in the soil in the conventional system was probably related to the negative impact of pesticides on these parameters. The results obtained by other authors confirm the sensitivity of microbial enzymes to pesticides (Baćmaga et al. 2016; Järvan et al. 2014).

The results obtained for the studied number of microorganisms and enzymatic activities suggest that bacteria in the organic system were primarily responsibility for the enzymatic activity and fungi in the conventional system. This supposition particularly applies to dehydrogenase activities, because dehydrogenases are present in living cells of soil microorganisms and are therefore used to assess changes occurring in this environment under the influence of various factors (Sebiomo et al. 2011; Wolińska and Stępniewska 2011).

\section{Community-level physiological profiling (CLPP) analysis using Biolog EcoPlates}

A method called community-level physiological profiling (CLPP), which is based on the utilization of various carbon sources by environmental microorganisms, is used in addition to enzymatic activity in the microbiological studies of the soil environment. The CLPP method is not used to assess the metabolic activity of single microorganisms, but whole populations of microorganisms from a given environment.

The results obtained in these studies have shown that determining the metabolic profile of soils is an important indicator of the quality of the soil environment in the 
cultivation of cereals in various systems. Differences in biological activity of soils in various plant cultivation systems have been demonstrated both in this work and in the studies of other authors (Gajda et al. 2016; Gałązka et al. 2017a, b; Grządziel and Gałązka 2018). Evaluation of soil metabolic profile in various plant cultivation systems is even more valuable if performed in several-year-old field experiments. The experiments conducted in this study found statistically significant differences in the metabolic profile of soils both in the cultivation of winter wheat, barley and oat in the conventional and organic systems. The soil collected from plant cultivation in the conventional system was characterized by significantly higher biodiversity indices (Shannnon, AWCD, Richness) compared with the organic system.

The use of Biolog ECO plates for the analysis of soil microbial communities provides new information on their functional diversity and can be used to observe changes occurring in the soil environment (Łyszcz and Gałazka 2016). This was confirmed by numerous studies based on the analysis of soil metabolism of arable soils (Gałazka and Grządziel 2018). Functional diversity of microorganisms is as important as structural diversity, because by performing various functions, microbiome participates in many processes occurring in the soil environment.

The results indicate that organic cultivation is more beneficial for microbiological balance and fertility of the soil. This is usually confirmed by higher enzymatic activity, nitrification and higher bacterial counts. These studies should be continued to confirm the trend of changes in the analyzed activities that persisted during the 3 -year study period.

\section{Conclusion}

The organic system was more beneficial for increasing abundance and activity of soil microorganisms and therefore for soil fertility, for which they are responsible. The conventional system caused an increase in the development of fungi. This phenomenon may in consequence lead to a negative impact on the biodiversity and phytosanitary status of the soil environment associated with the excessive occurrence of pathogenic species that produce antibiotics, mycotoxins or pathogens. Therefore, it is advisable to monitor long-term effects of a conventional crop system using microbiological activity parameters. Research on the analysis of soil microbial diversity is very important to understand the impact of climate change, agricultural activity and other anthropogenic factors on the activity of soil microbiome, which is associated with various biogeochemical processes and soil quality. Studying functional biodiversity of the soil environment is important for both obtaining better crop quality and maintaining environmental biodiversity.
The results showed that the organic system was more favorable for bacterial growth, dehydrogenase, protease and urease activities and nitrification.

Acknowledgements This work was financially supported by the University of Life Sciences in Lublin, Poland. The research was conducted within the frame of Task 1.4. Multi - Annual Programme IUNG - PIB (2016-2020).

\section{Compliance with ethical standards}

Conflict of interest The authors declare that they have no conflict of interest.

Open Access This article is licensed under a Creative Commons Attribution 4.0 International License, which permits use, sharing, adaptation, distribution and reproduction in any medium or format, as long as you give appropriate credit to the original author(s) and the source, provide a link to the Creative Commons licence, and indicate if changes were made. The images or other third party material in this article are included in the article's Creative Commons licence, unless indicated otherwise in a credit line to the material. If material is not included in the article's Creative Commons licence and your intended use is not permitted by statutory regulation or exceeds the permitted use, you will need to obtain permission directly from the copyright holder. To view a copy of this licence, visit http://creativecommons.org/licenses/by/4.0/.

\section{References}

Alef K, Nannipieri P (1995) Methods in applied soil microbiology and biochemistry, 1st edn. Academic Press, London

Anilkumar RR, Edison LK, Pradeep NS (2017) Exploitation of fungi and actinobacteria for sustainable agriculture. In: Patra JK, Vishnuprasad ChN, Das G (eds) Microbial biotechnology. Applications in agriculture and environment. Springer, Singapore, pp 135-162

Baćmaga M, Wyszkowska J, Kucharski J (2016) The effect of the Falcon 460 EC fungicide on soil microbial communities, enzyme activities and plant growth. Ecotoxicology 25:1575-1587. https ://doi.org/10.1007/s10646-016-1713-z

Breaz-Boruta B (2013) Effect of cropping system on development dynamics of cellulolytic microorganisms in soil. Environ Prot Nat Resour 24:41-44. https://doi.org/10.2478/oszn-2013-0021

Breza-Boruta B, Paluszak Z (2006) Occurrence of amylolytic microorganisms in soil depending on the type of cultivation. Ecohydrol Hydrobiol 6:175-180

Bünemann EK, Schwenke GD, Van Zwieten L (2006) Impact of agricultural inputs on soil organisms-a review. Aust J Soil Res 44:379-406. https://doi.org/10.1071/SR05125

Burns RG, DeForest JL, Marxsen J, Sinsabaugh RL, Stromberger ME, Wallenstein MD, Weintraub MN, Zoppini A (2013) Soil enzymes in a changing environment: current knowledge and future directions. Soil Biol Biochem 58:216-234. https://doi.org/10.1016/j. soilbio.2012.11.009

Caldwell AB (2005) Enzyme activities as a component of soil biodiversity: a review. Pedobiologia 49:637-644. https://doi.org/10.1016/j. pedobi.2005.06.003

Castillo JM, Romero E, Fernandez-Bayo J, Vivas A, Nogales R (2012) Effect of natural vegetation strips and herbicides on enzyme activities and bacterial diversity in olive-orchard systems. In: TrasarCepeda C, Hernandez T, Garcia C, Gonzalez-Carcedo S (eds) Soil 
enzymology in the recycling of organic wastes and environmental restoration. Springer, Dordrecht, pp 255-270

Chhotaray D, Achakzai AKK (2012) Relationship between soil microbial activities with organic and conventional farming systems. Int J Sustain Agric 4:64-68. https://doi.org/10.5829/idosi .ijsa.2012.04.03.2898

Crouzet O, Batisson I, Besse-Hoggan P, Bonnemoy F, Bardot C, Poly F, Bohatier J, Mallet C (2010) Response of soil microbial communities to the herbicide mesotrione: a dose-effect microcosm approach. Soil Biol Biochem 42:193-202. https://doi. org/10.1016/j.soilbio.2009.10.016

De Ponti T, Rijk B, van Ittersum MK (2012) The crop yield gap between organic and conventional agriculture. Agric Syst 108:19. https://doi.org/10.1016/j.agsy

Fließbach A, Oberholzer H-R, Gunst L, Mäder P (2007) Soil organic matter and biological soil quality indicators after 21 years of organic and conventional farming. Agric Ecosyst Environ 118:273-284. https://doi.org/10.1016/j.agee.2006.05.022

Frąc M, Jezierska-Tys S, Yaguchi T (2015) Occurrence, detection, and molecular and metabolic characterization of heat-resistant fungi in soils and plants and their risk to human health. Adv Agron 132:161-204. https://doi.org/10.1016/bs.agron.2015.02.003

Gajda AM, Czyż E, Dexter AR (2016) Effects of long-term use of different farming systems on some physical, chemical and microbiological parameters of soil quality. Int Agrophys 30:165-172. https://doi.org/10.1515/intag-2015-0081

Gałązka A, Grządziel J (2018) Fungal genetics and functional diversity of microbial communities in the soil under long-term monoculture of maize using different cultivation techniques. Front Microbiol. https://doi.org/10.3389/fmicb.2018.00076

Gałązka A, Gawryjołek K, Grządziel J, Księżak J (2017a) Effect of different agricultural management practices on soil biological parameters including glomalin fraction. Plant Soil Environ 63:300-306. https://doi.org/10.17221/207/2017-PSE

Gałązka A, Gawryjołek K, Perzyński A, Gałązka R, Księżak J (2017b) Changes in enzymatic activities and microbial communities in soil under long-term maize monoculture and crop rotation. Pol J Environ Stud 26:39-46. https://doi.org/10.15244 /pjoes/64745

Garland JL, Mills AL (1991) Classification and characterization of heterotrophic microbial communities on the basis of patterns of community-level sole-carbon-source utilization. Appl Environ Microbiol 57:2351-2359

Gomez E, Garland J, Conti M (2004) Reproducibility in the response of soil bacterial community-level physiological profiles from a land use intensification gradient. Appl Soil Ecol 26:21-30. https ://doi.org/10.1016/j.apsoil.2003.10.007

Gouda S, Nayak S, Bishwakarma S, Kerry RG, Das G, Patra JK (2017) Role of microbial technology in agricultural sustainability. In: Patra JK, Vishnuprasad ChN, Das G (eds) Microbial biotechnology. Applications in agriculture and environment. Springer, Singapore, pp 181-202

Grządziel J, Gałązka A (2018) Microplot long-term experiment reveals strong soil type influence on bacteria composition and its functional diversity. Appl Soil Ecol 124:117-123. https:// doi.org/10.1016/j.apsoil.2017.10.033

Haichar FZ, Santaella C, Heulin T, Achouak W (2014) Root exudates mediated interactions belowground. Soil Biol Biochem 77:69-80. https://doi.org/10.1016/j.soilbio.2014.06.017

Islam MR, Chauhan PS, Kim Y, Kim M, Sa T (2011) Community level functional diversity and enzyme activities in paddy soils under different long-term fertilizer management practices. Biol Fert Soils 47:599-604. https://doi.org/10.1007/s0037 4-010-0524-2

IUSS Working Group WRB (2015) World Reference Base for Soil Resources 2014, update 2015. International soil classification system for naming soils and creating legends for soil maps. World Soil Resources Reports No.106. FAO, Rome

Järvan M, Edesi L, Adamson A, Võsa T (2014) Soil microbial communities and dehydrogenase activity depending on farming systems. Plant Soil Environ 10:459-463

Joniec J (2018) Enzymatic activity as an indicator of regeneration processes in degraded soil reclaimed with various types of waste. Int J Environ Sci Technol 15:2241-2252. https://doi. org/10.1007/s13762-017-1602-x

Kinney CA, Mandernack KW, Mosier AR (2005) Laboratory investigations into the effects of the pesticides mancozeb, chlorothalonil, and prosulfuron on nitrous oxide and nitric oxide production in fertilized soil. Soil Biol Biochem 37:837-850. https:// doi.org/10.1016/j.soilbio.2004.07.044

Ladd JN, Butler JHA (1972) Short - term assays of soil proteolytic enzyme activities using proteins and dipeptide derivatives as substrates. Soil Biol Biochem 4:19-30. https://doi. org/10.1016/0038-0717(72)90038-7

Lang M, Cai Z (2009) Effects of chlorothalonil and carbendazim on nitrification and denitrification in soils. J Environ Sci 21:458467. https://doi.org/10.1016/S1001-0742(08)62292-5

Liang Q, Chen H, Gong Y, Yang H, Fan M, Kuzyakov Y (2014) Effects of 15 years of manure and mineral fertilizers on enzyme activities in particle-size fractions in a North China Plain soil. Eur J Soil Biol 60:112-119. https://doi.org/10.1016/j.ejsob i.2013.11.009

Łyszcz M, Gałązka A (2016) Selected molecular methods used in assessing the biodiversity of soil organisms. Postep Mikrobiol 55:309-319

Madejón E, Murillo JM, Moreno F, López MV, Arrue JL, AlvaroFuentes J, Cantero C (2009) Effect of long-term conservation tillage on soil biochemical properties in Mediterranean Spanish areas. Soil Tillage Res 105:55-62. https://doi.org/10.1016/j.still .2009 .05 .007

Martin JP (1950) Use of acid rose bengal and streptomycin in the plate method for estimating soil fungi. Soil Sci 69:215-232. https://doi.org/10.1097/00010694-195003000-00006

Mohammadi K (2011) Soil microbial activity and biomass as influenced by tillage and fertilization in wheat production. Am Eurasian J Agric Environ Sci 10:330-337

Mommer L, Kirkegaard J, Ruijven J (2016) Root-root interactions: towards a rhizosphere framework. Trends Plant Sci 21:209-217. https://doi.org/10.1016/j.tplants.2016.01.009

Nannipieri P, Kandeler E, Ruggiero P (2002) Enzyme activities and microbial and biochemical processes in soil. In: Burns RG, Dick RP (eds) Enzymes in the environment. Marcel, Dekker, New York, pp 1-34

Nowosielski O (1974) Methods for determination of fertilization demand, 2nd edn. PWRiL, Warsaw

Oszust K, Frąc M, Gryta A, Bilińska N (2014) The influence of ecological and conventional plant production systems on soil microbial quality under hops (Humulus lulus). Int J Mol Sci 15:9907-9923. https://doi.org/10.3390/ijms 15069907

Pajares S, Gallardo J, Etchevers D (2012) Enzymatic activity and carbon mineralization in Mexican tepetates cultivated under different management practices. In: Trasar-Cepeda C, Hernandez T, Garcia C, Gonzalez-Carcedo S (eds) Soil enzymology in the recycling of organic wastes and environmental restoration. Springer, Dordrecht, pp 51-62

Pohland B, Owen B (2009) Biolog EcoPlates standard methods. TAS Tech Bull Biol 1:1-3

R4P Network (2016) Trends and challenges in pesticide resistance detection. Trends Plant Sci 21:834-853. https://doi. org/10.1016/j.tplants.2016.06.006

Sebiomo A, Ogundero VW, Bankole SA (2011) Effect of four herbicides on microbial population, soil organic matter and 
dehydrogenase activity. Afr J Biotechnol 10:770-778. https:// doi.org/10.5897/AJB10.989

Seufert V, Ramankutty N, Foley JA (2012) Comparing the yields of organic and conventional agriculture. Nature 485:229-232. https://doi.org/10.1038/nature11069

Stephens EC, Jones AD, Parsons D (2018) Agricultural systems research and global food security in the 21st century: An overview and roadmap for future opportunities. Agric Syst 163:1-6. https://doi.org/10.1016/j.agsy.2017.01.011

Thalmann A (1968) Zur Methodik der Bestimmung der dehydrogenaseactivität im boden mittels triphenyltetrazoliumchlorid (TTC). Landwirt Forsch 21:249-258

Trolldenier G (1995) Bacterial biomass. In: Schinner F, Öhlinger R, Kandeler E, Margesin R (eds) Methods in soil biology. Springer Press, Berlin, pp 12-46
Upadhyay LSB, Dutt A (2017) Microbial detoxification of residual organophosphate pesticides in agricultural practis. In: Patra JK, Vishnuprasad ChN, Das G (eds) Microbial biotechnology. Applications in agriculture and environment. Springer, Singapore, pp 225-242

Wolińska A, Stępniewska Z (2011) Microorganisms abundance and dehydrogenase activity as a consequence of soil reoxidation process. In: Miransari M (ed) Soil tillage and microbial activity. Singpost Research, India, pp 111-143

Zantua MI, Bremner JM (1975) Comparison of methods of assaying urease activity in soils. Soil Biol Biochem 7:291-295. https://doi. org/10.1016/0038-0717(75)90069-3

Zhang Ch, Liu X, Dong F, Xu J, Zheng Y, Li J (2010) Soil microbial communities response to herbicide 2,4-dichlorophenoxyacetic acid butyl ester. Eur J Soil Biol 46:175-180. https://doi. org/10.1016/j.ejsobi.2009.12.005 